\title{
Leadership Style in Amateur Club Sports: A Key Element in Strategic Management
}

\author{
Alfonso Martínez-Moreno *DiD, Francisco Cavas-García and Arturo Díaz-Suárez \\ Faculty of Sport Sciences, University of Murcia, 30720 Santiago de la Ribera-San Javier, Spain; \\ francisco.cavas@um.es (F.C.-G.); ardiaz@um.es (A.D.-S.) \\ * Correspondence: almamo@um.es
}

Citation: Martínez-Moreno, A.; Cavas-García, F.; Díaz-Suárez, A Leadership Style in Amateur Club Sports: A Key Element in Strategic Management. Sustainability 2021, 13, 730. https://doi.org/10.3390/ su13020730

Received: 28 October 2020 Accepted: 8 January 2021 Published: 13 January 2021

Publisher's Note: MDPI stays neutral with regard to jurisdictional clai$\mathrm{ms}$ in published maps and institutional affiliations.

Copyright: $(\odot 2021$ by the authors. Licensee MDPI, Basel, Switzerland. This article is an open access article distributed under the terms and conditions of the Creative Commons Attribution (CC BY) license (https:// creativecommons.org/licenses/by/ $4.0 /)$.

\begin{abstract}
Leadership is key in sports management, as it allows organizations to endure over time. Leadership style determines how an organization or sports club works. The purpose of this study is to investigate employees' perceptions of the leadership style of presidents (managers) in amateur clubs and how it influences the effort, efficiency and satisfaction of those employees. The sample consists of club managers $(n=334)$, of whom 286 are men and 48 are women, with an average age of 42.05 ( \pm 9.64 ). The subordinate version of the Multifactorial Leadership Questionnaire is used, and it is found that club presidents mostly use the transformational style, regardless of sports discipline. A descriptive analysis of the qualitative variables consists of absolute and relative frequencies. ANOVA is used for comparisons between groups, and forward multiple regression is used to determine the effects of different variables. There are significant differences between the managers of collective and individual sports clubs in terms of efficiency $(p=0.014)$ and satisfaction $(p=0.04)$. Leadership style had significant effects on effort, effectiveness and satisfaction, while the genre and type of sport did not, corroborating the positive predictive power of the transformational and transactional styles. Transformational and transactional leadership styles positively and statistically significantly predict the extra effort of subordinates, the perceived effectiveness of leadership and satisfaction with the leader. Leadership training brings advantages in the stability and sustainability of sports clubs.
\end{abstract}

Keywords: leadership; strategic managers; sport; amateur clubs

\section{Introduction}

Leadership mixes tangible and intangible elements within organizations. A leader must create a positive emotional environment, which has an impact on work efficiency [1]. Leaders use words and actions as tools to lead organizations to success [2,3], and use their influence, abilities and knowledge to help groups achieve objectives [4].

Leadership is the result of an intersectional process in which the objectives, the leader and the followers must be taken into account [5]. In the literature on types of leadership, there is no clear consensus on how to measure the capacity for leadership, or the types of leadership that exist [6]. Hence, the definition of leadership is not without its problems [7].

\subsection{Leadership Styles}

Various theories have been developed concerning leadership, each emphasizing different aspects: the theory of traits and roles (which highlights the attributes of the leader) $[8,9]$, the theory of situational leadership (which places emphasis on the context and evolution of the group) [10], the theory of transformational leadership (which identifies leadership not as an attribute but as a behavior) [11] and the theory of transactional leadership (which places emphasis on the leader's relationship with the group and its basic needs) [12]. However, the theory of transformational leadership [13] is the most accepted theory, and it concentrates on how organizations and the human capital that supports them transform under different styles of leadership. Transformative leadership can be differentiated from 
transactional leadership in terms of the dimensions used to describe them: transformative leadership is described in terms of behavior, attributions, inspiring motivation and intellectual stimulation, whereas transactional leadership is described in terms of individual considerations, rewards and a laissez-faire style [14]. Transactional leadership deals with the effectiveness of employee performances, and transformational leadership is directed towards the workers' sense of pride in the work done, arousing high levels of motivation, satisfaction and effectiveness [15]. In addition, the laissez-faire (or nonleadership) style is described as a passive leadership style in which leaders avoid interaction with their followers and maintain great social distances [16], and is associated with high levels of dissatisfaction, conflict and ineffectiveness on the part of their workers [13].

Currently, there has been discussion concerning emerging leadership in organizations [17]. A good leader is one who puts their strategic, tactical, operational and human knowledge at the service of the organization [18]. They must be a person who stimulates and encourages collective participation and focuses on commitment and responsibility in order to respond to the complex changes taking place in society [19]. Leaders need to motivate followers to make changes and contribute to the desired outcomes [20]. Today's leaders must provide responsible guidance, be willing to play more proactive roles and initiate multistakeholder initiatives and technological innovations [21]. These new needs favor the transformational leader style [22]. Transformational leadership seems to have an intense influence on the organizational learning process and thus improves innovation, performance and competitiveness. It is also a positive influence on an organization's commitment to change $[23,24]$. Studies have shown that there is a strong relationship between team cohesion and success and that team cohesion is related to leadership behavior [25]. Leadership is important for sports clubs because there is a consensus that leadership is necessary to guide organizations and human resources towards strategic objectives [26], in addition to the fact that good leadership is key to the performance of a sports team/organization $[27,28]$ and its ability to grow and endure over time.

Hypothesis 1. The leadership styles most used by the directors of amateur sports clubs are transformational and transactional.

\subsection{Management in Sports Organizations}

Sports management is important for making sport valuable and meaningful, similar to how companies make their products valuable to customers [29]. The literature related to the organizational management of organizations and leadership styles indicates the existence of a relationship between leadership, management and business results [30]. Among the organizational elements that influence people's behavior and engagement with an organization or team are transformational and transactional leadership styles [31]. Leadership is key for the nonprofit sports sector [32].

Furthermore, the approach to sports governance by managers is often characterized by a "leisure mentality" rather than a more objective business approach to governance [33]. The complexity of the internal and external environments of most sports organizations often requires an understanding of the entire organization and multiple levels of leadership experience [34]. Leadership behaviors can have both positive and negative consequences on job satisfaction [35-37]. Given changing work environments, Salacuse [38] suggests that staff must be more educated and intelligent than ever before, and leaders must lead by negotiation. Antoldi et al. [39] indicate that the clubs they analyzed needed to provide a pool of professional managers and advisors for their members, moving from an "amateur" or "voluntary" way of thinking to a more structured and professional approach.

Today's organizations must adapt to a globally competitive environment, which exerts an exponential pressure on performance [40]. All of these changes jeopardize the stability of some organizations [41]. In today's organizational environments, new forms of work are required, meaning that organizations require leadership and innovation [42,43]. The process of mobilization and social change is underpinned by two elements, that is, 
leadership and community resilience [44]. Organizational adaptation demands certain changes in organizational policies, including greater transformational leadership, which can influence people to perceive their work more positively [45].

Hypothesis 2. Leadership styles predict extra effort from subordinates and increased satisfaction.

\subsection{Justification of the Study}

Leadership style in amateur sports clubs can help to make fewer mistakes in daily and future decisions, as well as provide an environment that helps clubs live longer. The sports club environment brings additional difficulties to the decisions that must be made in any organization, since the decisions are conditioned by the uncertainty of the results. Today, clubs, as organizations, are increasingly facing demanding customer-users with great knowledge of their needs and the characteristics they want to see in products. This situation requires that organizations and/or clubs seek tools/strategies to help them survive in this competitive global landscape. Hence, the type of leadership has become vital due to the impact it has on individual motivation and performance. While the survival of an organization depends on its leaders, the leadership style used reflects the nature of the organization and its relationship with the community.

This is enhanced if we review the management of the clubs from a gender perspective, since, historically, sport is a male space both in its practice and its management. This is integrated into the organizational structure of sport, which makes it difficult for women to access leadership positions, excluding them from decision-making bodies and making them invisible [46]. Studies on sports management positions identify and point to a number of barriers and limits to the promotion of women in decision-making positions [47]. There are infinite barriers for women, making it difficult for them to hold management positions on an equal footing with men, with the same opportunities within organizations [48], even though gender diversity has been found to significantly reduce human and financial resource problems in sports clubs [49]. Administrations are currently establishing quotas by gender to correct these differences.

In complex organizations and sports clubs (managers, coaches, athletes, parents, amateurs, referees), there are no correct or incorrect leadership styles [50]. Hence, people trained in leadership must be able to promote the changes and innovations required in their organizations [41].

Leadership styles have changed according to the needs and requirements of modern organizations [51]. Leadership styles have been studied in many fields, including education [52-54], policing [55,56], and health [57,58]. The field of sports management lacks studies that have investigated combined leadership and governance [59]. In terms of clubs, there is a notable absence of focus on leadership issues [60-62]. There are some studies, such as that of Jian and Chen [63], which have explored the types of leadership used on boards of directors of sports systems, but few studies have looked into understanding clubs as organizations/companies.

Amateur organizations are vulnerable because of their size, lack of formal skills and weak and undefined organizational structure [64]. The environment of the nonprofit sports sectors has become more complex than ever [36,65]. A vital factor in improving organizational performance, organizational failure and success is effective leadership at all levels [66].

The study of Barbado and Martínez-Moreno [67] on workers' perceptions of the leadership styles used in fitness centers, that of Arriola [68] on the coaches of a sports club and that of Burmaoglu [69] analyzing the relationship between the service leadership and ability of managers with the organizational trust of sports clubs staffs in Erzurum are some of the studies related to this object of study.

Thus, the importance of this study lies in its examination of the style of leadership as the basis of the sustainability and stability of clubs over time. An effective leader has been shown to facilitate substantive achievements and improvements in employees 
and organizational productivity [70-73]. Leadership in business developments can lead to the empowerment of workers [53]. Organizations should consider empowerment, innovation and leadership as relevant and impactful factors in achieving competitive advantages [74]. It is more common to find subordinates with a high level of extraversion, awareness and kindness in organizations where there is an environment of transformational leadership [75].

Ferkins et al. [60] indicate that little research has been done on leadership in relation to boards of directors in all sectors-private, public and amateur-of sports organizations, and that it was time for leadership literature to play a more important role in informing governance literature and vice versa. An essential requirement for strengthening today's sports organizations is to investigate how the work experiences and well-being of sports employees can be improved [29].

If the success of an organization depends largely on people and how they do their work, the effort they put into that work becomes a major element to be developed in these organizations. By effort, we mean the energy/strength/performance with which individuals/organizations face a difficulty or aim to achieve a goal. Closely linked to effort is satisfaction, which is directly proportional to the workers' involvement in the organization. Satisfaction is a person's general attitude towards their work, where their beliefs, values and interactions with colleagues and superiors are framed. Both effort and satisfaction are needed, along with efficiency, to make up an excellent employee. By limiting efficiency, organizations lose out on using the least number of resources to achieve an objective, or even achieving more with the same or fewer resources.

All of the above leads us to consider the following objectives for this study: (i) investigate the leadership styles of amateur club presidents in collective, individual and adversarial sports; and (ii) determine the influence of the style of leadership used on the efforts, satisfaction and effectiveness of subordinates.

\section{Materials and Methods}

A nonexperimental, observational, transversal, descriptive and correlational study was carried out using a quantitative research design, with similarities to other investigations [76-78].

\subsection{Participants}

The sample was collected through convenience sampling. The selection of this type of sampling is justified on the basis of economic costs and the time spent in collecting responses, which is common in studies of this type [79-82]. The sample was made up of the directors $(n=334)$ of amateur sports clubs in Spain from 20 sports: the group sports of football (156 directors), basketball (37), indoor football (25), volleyball (9), rugby (6), water polo (12) and paddle (3); the individual sports of tennis (10), badminton (6), rhythmic gymnastics (7), skating (3), triathlon (6), equestrianism (3), swimming (6), athletics (11) and canoeing (3); and the oppositional sports of taekwondo (9), judo (9), karate (6) and wrestling (7). Of these 334 managers, 286 were men and 48 were women, with an average age of $42.05( \pm 9.64)$, and they were led by 79 presidents. Law 10/1990 [83] on sport in Spain determines that amateur sports clubs are private associations, constituted by natural or legal persons, whose aim is to promote one or more sports modalities and the practice of these modalities by their members, as well as to participate in sports activities and competitions. It also indicates that amateur athletes are all those persons who practice a sport within a club, receiving from the club only the compensation for the expenses derived from their sports practice. In terms of the levels of study of the participants, more than one-third (35.9\%) had completed high school, $12.6 \%$ had a primary education, $6.3 \%$ were physical education graduates, $13.8 \%$ had a degree in physical education and almost another third $(31.4 \%)$ had other university qualifications. The managerial positions held were secretary $(17.7 \%)$, treasurer $(10.8 \%)$, vice president $(18.3 \%)$, vocal $(15 \%)$ and other functions $(38.4 \%)$. Anyone on the management team of a club at the time of the investigation could participate in this study, with the exception of the president of the club. Club presidents 
were ruled out, as the object of the study was to find out how their subordinates perceived leadership style and other variables. The sample of 334 subjects was left after eliminating 12 questionnaires that were incomplete.

\subsection{Instruments}

The Spanish subordinate version of the Multifactorial Leadership Questionnaire (MLQ5X) [84] developed by Molero et al. [85] was administered. The instrument consists of 45 items, 36 of which cover four types of leadership [85]: transformational leadership (idealized attribution influence, idealized influencing behavior, inspirational motivation and intellectual stimulation) with 16 items, facilitating leadership with developmental and/or transformational elements (transformational factor of individualized consideration and the transactional factor of contingent rewards) with 8 items, corrective leadership (direction via active exception) with 4 items and passive/avoidant leadership (direction via exception (laissez-faire) with 8 items. The remaining nine items collect information about strengthening the board as a result of the president's conduct (three items), the president's effectiveness as a leader (four items) and associations with the club president as a leader (two items). The questionnaire begins with the phrase "My president ... ", and responses to individual items are marked on a Likert scale with a range of 0 (never) to 4 (almost always). Examples of items include "Speaks optimistically about the future", "Takes time to respond to urgent topics" and "Spends time teaching and training the group".

\subsection{Procedures}

After contacting the different clubs and explaining the purpose of the investigation, visits were arranged for the administration of the questionnaires. Participation was voluntary and anonymous. All participants signed informed consent in accordance with the principles of the Helsinki Declaration [86]. Approval was sought from the Committee on Research Ethics of the University of Murcia, which determined that the study, despite using human subjects, was observational and therefore did not require committee approval.

\subsection{Statistical Analysis}

A nonexperimental study (i.e., an observational, transversal, descriptive and correlational study) was carried out using a quantitative research design. A descriptive analysis of the qualitative variables involving absolute and relative frequencies was performed. ANOVA was used for comparisons between groups, and forward multiple regression was used to determine the effects of different variables. Statistical analyses were performed using SPSS 25.0 for Windows (IBM, New York, NY, USA), and a significance level of $p<0.05$ was assigned to all tests.

\section{Results}

Table 1 shows the correlations between the leadership styles and the result factors. The developer/transactional and corrective transformational leadership styles relate positively and significantly to the three outcome factors-extra effort, efficiency and satisfaction. However, the passive/avoidant style is negatively and statistically significantly related to efficiency and satisfaction.

The relation between leadership style and extra effort depends on the type of sport (see Table 2). The subordinates of the managers of sports clubs, whether they are managers for group, individual or adversarial sports clubs, mostly perceive that their leaders (presidents) prefer using transformational leadership. There are significant differences between the managers of group sports clubs $(p=<0.01)$ and those of individual and adversarial sports clubs. There are also significant differences in efficiency between the managers of group and individual sports clubs $(p=0.014)$ and those of adversarial sports clubs, as well as differences between group and individual sports managers and adversarial sports managers $(p=0.04)$. Among the remaining variables, there were no significant differences, which indicates that these variables are not associated or correlated. 
Table 1. Bivariate correlations between leadership styles and result factors.

\begin{tabular}{ccccccc}
\hline Leadership Styles & $\mathbf{1}$ & $\mathbf{2}$ & $\mathbf{3}$ & $\mathbf{4}$ & $\mathbf{5}$ & $\mathbf{6}$ \\
\hline 1. Transformational & 1 & - & - & - & - & - \\
2. Developer/Transactional & $0.72^{* * *}$ & 1 & - & - & - & - \\
3. Corrective & $0.64^{* * *}$ & $0.44^{* *}$ & 1 & - & - & - \\
4. Passive/avoidant & $-0.37^{* * *}$ & -0.08 & $-0.38^{* *}$ & 1 & - & - \\
Result factors & - & - & - & - & -0.08 & 1 \\
5. Effort & $0.58^{* * *}$ & $0.45^{* * *}$ & $0.36^{* * *}$ & $-0.31^{*}$ & $0.74^{* * *}$ & 1 \\
6. Efficiency & $0.59^{* * *}$ & $0.55^{* * *}$ & $0.41^{* * *}$ & $-0.38^{* *}$ & $0.57^{* * *}$ & $0.65^{* * *}$ \\
7. Satisfaction & $0.65^{* * *}$ & $0.53^{* * *}$ & $0.43^{* * *}$ & -
\end{tabular}

Note: ${ }^{*} p<0.05,{ }^{* *} p<0.01,{ }^{* * *} p<0.001$.

Table 2. Leadership styles and extra effort depending on the type of sport.

\begin{tabular}{ccccc}
\hline \multirow{2}{*}{ Leadership Styles } & \multicolumn{3}{c}{ Sport Type } & \multirow{2}{*}{$p$-Value } \\
\cline { 2 - 4 } & Group & Individual & Adversarial & \\
\hline Transformational Leadership & $3.23(0.4)$ & $3.31(0.37)$ & $3.38(0.36)$ & 0.305 \\
Developer/Transactional & $2.95(0.48) \mathrm{a}$ & $3.21(0.41) \mathrm{b}$ & $3.32(0.37) \mathrm{b}$ & 0.0 \\
Leadership & $3.13(0.54)$ & $3.22(0.51)$ & $3.1(0.42)$ & 0.257 \\
Corrective Leadership & $1.03(0.77)$ & $1.06(0.81)$ & $0.8(0.55)$ & 0.213 \\
Passive/avoidant Leadership & $3.17(0.63)$ & $3.26(0.53)$ & $3.37(0.57)$ & 0.219 \\
Effort & $3.06(0.59) \mathrm{a}$ & $3.17(0.57) \mathrm{a}$ & $3.4(0.49) \mathrm{b}$ & 0.014 \\
Efficiency & $3.09(0.66) \mathrm{a}$ & $3.25(0.53) \mathrm{a}$ & $3.37(0.39) \mathrm{b}$ & 0.04 \\
Satisfaction & &
\end{tabular}

Note: $p<0.05$. a,b: two-to-two column comparisons. Between two different columns, the letters indicate statistically significant differences (Bonferroni correction).

In order to determine the effect of the variables sex, type of sport and type of leadership on the efficiency and satisfaction variables, forward multiple regressions were performed. Neither sex nor sport had significant effects. Transactional leadership was introduced in the first step, and transformational leadership was introduced in the second. Table 3 shows the hierarchical regression in relation to effort. Transformational leadership influences effort; therefore, the more pronounced the transformational leadership, the greater the effort. The passive/avoidant style had less significance.

Table 3. Hierarchical regression analysis for effort.

\begin{tabular}{|c|c|c|c|c|c|c|}
\hline Step & B (ET) & B & $\mathrm{T}$ & $\mathbf{R}^{2}$ & $\Delta \mathbf{R}^{2}$ & F (g.l.) \\
\hline 1 & & & & 0.33 & & $\mathrm{~F}(1 ; 304) \times 152.74^{* * *}$ \\
\hline L Developer/Transactional & $0.89(0.07)$ & 0.58 & $12.36^{* * *}$ & & & \\
\hline 2 & & & & 0.34 & 0.01 & $\mathrm{~F}(2 ; 303) \times 79.48^{* * *}$ \\
\hline L Transformational & $0.93(0.07)$ & 0.61 & $12.53 * * *$ & & & \\
\hline L Passive/avoidant & $0.07(0.03)$ & 0.10 & $2.12 *$ & & & \\
\hline
\end{tabular}

Table 4 presents the regression results for efficiency. Both transformational and transactional leadership positively influence efficiency.

Table 4. Hierarchical regression analysis for efficiency.

\begin{tabular}{|c|c|c|c|c|c|c|}
\hline Step & B (ET) & B & $\mathrm{T}$ & $\mathbf{R}^{2}$ & $\Delta \mathbf{R}^{2}$ & F (g.l.) \\
\hline 1 & & & & 0.34 & & $\mathrm{~F}(1 ; 306) \times 157.73^{* * *}$ \\
\hline L Developer/Transactional & $0.85(0.07)$ & 0.58 & $12.56^{* * *}$ & & & \\
\hline 2 & & & & 0.37 & 0.03 & $\mathrm{~F}(2 ; 305) \times 90.18^{* * *}$ \\
\hline L Transformational & $0.58(0.1)$ & 0.4 & $6.06^{* * *}$ & & & \\
\hline L Developer/Transactional & $0.32(0.08)$ & 0.26 & $3.91^{* * *}$ & & & \\
\hline
\end{tabular}


In Table 5, we can see that both transformational and transactional leadership significantly influence satisfaction. So, the more pronounced the transformational or transactional leadership, the greater the satisfaction of subordinates.

Table 5. Hierarchical regression analysis for satisfaction.

\begin{tabular}{|c|c|c|c|c|c|c|}
\hline Step & B (ET) & B & $T$ & $R^{2}$ & $\Delta R^{2}$ & $F$ (g.1.) \\
\hline 1 & & & & 0.41 & & $\mathrm{~F}(1 ; 306) \times 218.23^{* * *}$ \\
\hline L Transactional & $1.02(0.07)$ & 0.65 & $14.77^{* * *}$ & & & \\
\hline 2 & & & & 0.43 & 0.011 & $\mathrm{~F}(2 ; 305) \times 114.33^{* * *}$ \\
\hline L Transformational & $0.83(0.1)$ & 0.53 & $8.43^{* * *}$ & & & \\
\hline L Developer/Transactional & $0.21(0.08)$ & 0.16 & $2.55^{*}$ & & & \\
\hline
\end{tabular}

\section{Discussion}

This study analyzed the leadership styles of amateur club presidents for group, individual and adversarial sports, and examined the influence of the leadership style used in terms of the efforts, satisfaction and effectiveness of the club managers.

Hypothesis one was confirmed (i.e., the leadership styles most used by the directors of amateur sports clubs are transformational and transactional). The managers mostly perceived that their presidents used the transformational leadership style, coinciding with the findings of Martínez-Moreno et al. [87], where cruise crew members witnessed a high level of transformative leadership, Arriola [68], who investigated sports coaches, Niño and Parra [88], who surveyed private security personnel, and Rivera [89], who investigated the perceptions of female heads and supervisors' collaborators. This study also agrees with Rabanal and Huamán [90], who emphasized that office heads most commonly used the transformational leadership style, Morales et al. [91], who found the same results for teachers, Martínez-Moreno et al. [92], who studied sports science students, and Alvarez et al. [5], who obtained the same results for local policemen. Similarly, Álvarez et al. [93] indicated that transformational leadership relates to healthier and more effective motivational styles. However, we do not agree with Barbado and Martínez-Moreno [67], who found that workers' perceptions of the leadership styles at fitness centers indicated that they were laissez-faire or passive. Therefore, in our case, the managers considered their leaders (presidents) best suited to drive the processes of change and innovation. Consequently, managers felt that they are important to their organizations and perceive themselves as using the same style of transformational leadership in the future.

Although the transformational leadership style scored highest in this study, it was closely followed by transactional leadership, coinciding with the findings of García-Morales et al. [94], who indicate that leaders use both transactional and transformational leadership to varying degrees. The first style is used to reward and compensate employees for contributions to transformation and deliberate change, while the second style is used to bond emotionally with employees to inspire and motivate them to accept transformation and deliberate change as a personal imperative.

Hypothesis two was also confirmed (i.e., leadership styles predict extra effort from subordinates and increased satisfaction). The results confirm that these relationships statistically significantly predicted the extra effort of subordinates, perceived leadership effectiveness and satisfaction with the leader. These findings corroborate previous studies [95-100] that have found significant associations between transformational leadership and job satisfaction. That being said, a combination of styles is more effective, since no single leadership style is the best [101].

In short, the subordinates of the sports club presidents in the sample exerted higher levels of effort, were more efficient and were more satisfied with their leaders, with significant differences between group and individual sports and adversarial sports. 


\section{Conclusions}

Transformational leadership helps leaders adapt in complex and dynamic socioecological systems such as amateur sports clubs.

With the help of amateur sports club managers, this study has corroborated the assumptions of the transformational leadership theory and brought cross-cultural validity to that theory. Based on the data, it is recommended that the presidents of sports clubs use transformational, developer/transactional and corrective leadership behaviors to benefit their subordinates.

\subsection{Limitations and Future Lines of Research}

The work has some limitations. First, convenience sampling was used, so we must be cautious in generalizing the results. Another limitation is the nonhomogeneity of the sample, although this is a reflection of reality, since it is mainly men who direct and manage sports clubs. As for future lines of research, we would like to analyze other leadership styles and profiles in order to determine what styles are most effective in the management of amateur sports clubs.

\subsection{Managerial Implications}

The results of the research lead us to demand specific training for managers from sports federations (as is done with coaches and referees). It would be beneficial for managers to obtain a minimum training in the leadership and management of organizations, as well as in other areas necessary for the proper management of sports clubs. As has been demonstrated with coaches [102-105] and referees [106-108], the completion of specific training leads to considerable evolution and improvement in sport. This will lead to more professional managers, which will translate to the increased stability and permanence of amateur sport clubs. Seeing as how presidents and managers will have tools that help them in their decisions to manage their sports clubs, this will also lead to the efficient management of amateur clubs.

Author Contributions: Conceptualization, A.M.-M.; methodology, F.C.-G. and A.D.-S.; validation, A.M.-M. and F.C.-G.; formal analysis, A.M.-M. and F.C.-G.; investigation, A.M.-M.; resources, F.C.-G. and A.D.-S.; data curation, F.C.-G. and A.D.-S.; writing-original draft preparation, A.M.-M. and F.C.G.; writing - review and editing, A.M.-M. and F.C.-G.; visualization, F.C.-G. and A.D.-S.; supervision, A.M.-M. and F.C.-G.; project administration, A.M.-M.; funding acquisition, F.C.-G. and A.M.-M. All authors have read and agreed to the published version of the manuscript.

Funding: This research received no external funding.

Institutional Review Board Statement: Ethical review and approval were waived for this study, because although it was a human study, it was observational, and the research design did not involve ethical issues.

Informed Consent Statement: Informed consent was obtained from all subjects involved in the study.

Data Availability Statement: Data sharing not applicable.

Acknowledgments: Thanks go to L. Stahl, for their invaluable help with the English of the article.

Conflicts of Interest: The authors declare no conflict of interest.

\section{References}

1. López, S. Un líder resonante. Dedic. Rev. Educ. Humanid. 2014, 6, 261-271. Available online: https://digibug.ugr.es/bitstream/ handle/10481/46028/17\%20-\%20Susana\%20Lopez\%20Tocon.pdf?sequence=1\&isAllowed=y (accessed on 22 December 2020).

2. Vásquez, A. La posmodernidad. Nuevo régimen de verdad, violencia metafísica y fin de los metarrelatos. Nómadas Rev. Crít. Cienc. Soc. Juríd. 2011, 29, 1-17. Available online: https://www.redalyc.org/articulo.oa?id=181/18118941015 (accessed on 3 September 2020). [CrossRef] 
3. Arrelucea, E.P.G.; Miranda, A.Y.V.; Pesantes, E.G. Gerencia de proyectos bajo el enfoque del Project Management Institute para garantizar su éxito en la empresa Encoservice. Ing. Cienc. Tecnol. Innov. 2017, 4, 1-16. Available online: http://revistas.uss.edu. pe/index.php/ING/article/view/722 (accessed on 28 August 2020).

4. Çaliş, Ç.; Büyükakinci, B.Y. Leadership approach in occupational safety: Taiwan sample. Proc. Comput. Sci. 2019, 158, 10521057.[CrossRef]

5. Bohórquez, M.R.; Checa, I. Escala de liderazgo en entrenadores de fútbol: Estudio psicométrico y descriptivo. Inf. Psicol. 2020, 119, 65-77.

6. Dinh, J.; Lord, R.; Garnder, W.; Meuser, J.; Liden, R.C.; Hu, J. Leadership theory and research in the new millennium: Current theoretical trends and changing perspectives. Leadersh. Q. 2014, 25, 36-62. [CrossRef]

7. Gould, D.; Voleker, D.K. Youth sport leadership development: Leveraging the sport captaincy experience. J. Sport Psychol. Action 2010, 1, 1-14. [CrossRef]

8. Mintzberg, H. The Nature of Managerial Work; Harper \& Row: New York, NY, USA, 1973.

9. Osborn, R.; Hunt, J.; Jauch, L. Toward a contextual theory of leadership. Leadersh. Q. 2002, 13, 797-837. [CrossRef]

10. Hersey, P.; Blanchard, K. Management of Organizational Behavior; Prentice Hall: New Jersey, NJ, USA, 1969.

11. Bass, B.; Avolio, B.J. Manual for the Multifactor Leadership Questionnaire; Mind Garden, Inc.: Redwood City, CA, USA, 2006.

12. Bass, B.; Avolio, B.; Jung, D.; Berson, Y. Predicting unit performance by assessing transformational and transactional leadership. J. Appl. Psychol. 2003, 88, 207-218. [CrossRef]

13. Bass, B.M. Two decades of research and development in transformational. Leadership. Eur. J. Work Organ. Psychol. 1999, 8, 9-32. [CrossRef]

14. Bass, B.M.; Avolio, B.J. Revised Manual for the Multifactor Leadership Questionnaire; Mind Garden: Palo Alto, CA, USA, 1997.

15. Belias, D.; Koustelios, A. Leadership and job satisfaction, a review. Eur. Sci. J. 2014, 10, $24-46$.

16. Hinkin, T.R.; Schriesheim, C.A. A theoretical and empirical examination of the transaction and not leadership dimensions of the management of the Multifactorial Questionnaire (MLQ). Leadersh. Q. 2008, 19, 501-513. [CrossRef]

17. Finol, D. Liderazgo resiliente ante escenarios prospectivos. Rev. Investig. Sigma 2019, 6, 28-39. Available online: https: / / dialnet.unirioja.es/servlet/articulo?codigo=7338194 (accessed on 20 August 2020). [CrossRef]

18. Baena-Ordosgoita, A. Liderazgo: Pieza clave en el éxito organizacional. Rev. Cient. Anfibios 2019, 2, 54-59. [CrossRef]

19. Aldana, J.; Salón, M.; Guzmán, N. Liderazgo sistémico en las competencias gerenciales docentes universitarios. Cienciamatria 2019, 5, 50-74. Available online: https:/ / cienciamatriarevista.org.ve/index.php/cm/article/view/87 (accessed on 20 August 2020). [CrossRef]

20. Hernández-Galván, M.P.; Vargas-Salgado, M.M. El liderazgo transformacional y su impacto en el cambio organizacional y la comunicación interna. Tur. Estud. Práct. 2020, 9, 1-5.

21. Maak, T.; Pless, N.M.; Voegtlin, C. Business statesman or shareholder advocate? CEO responsible leadership styles and the microfoundations of political CSR. J. Manag. Stud. 2016, 53, 463-493. [CrossRef]

22. Castro, G.N.D. El liderazgo transformacional como una opción de crecimiento para los empresarios. In Libros Universidad Nacional Abierta ya Distancia; Prospecta: Bogotá, Colombia, 2017.

23. Rivera, M. Determinant factors for small business to achieve innovation. High performance and competitiveness: Organizational learning and leadership style. In Proceedings of the 6th Indonesia International Conference on Innovation, Entrepreneurship, and Small Business, Bali, Indonesia, 12-14 August 2014; pp. 43-52.

24. Hill, N.; Seo, M.G.; Kang, J.; Taylor, M.S. Building employee commitment to change across organizational levels: The influence of hierarchical distance and direct managers' transformational leadership. Organ. Sci. 2012, 23, 758-777. [CrossRef]

25. Ramzaninezhad, R.; Keshtan, M.H. The relationship between coach's leadership styles and team cohesion in Iran football clubs professional league. Braz. J. Biomot. 2017, 3, 111-120.

26. Zaccaro, S.J.; Rittman, A.L.; Marks, M.A. Team leadership. Leadersh. Q. 2001, 12, 451-483. [CrossRef]

27. Casales, J.C.; González, E.; Caballero, A. Estilos de Dirección, Liderazgo, Procesos Grupales y Resultados Competitivos en Equipos de Fútbol Sala; Universidad de la Habana: La Habana, Cuba, 2013. Available online: http:/ /www.monografias.com/trabajos96/estilos-direccionliderazgo-equipos-futbol-sala/estilos-direccion-liderazgo-equipos-futbol-sala.shtml (accessed on 20 August 2020).

28. Hernández, A.; Canto, J. El liderazgo en los grupos deportivos. In Psicología del Deporte, Volume 1-Fundamentos 2; Hernández, A., Ed.; Editorial Wanceulen, S.L.: Buenos Aires, Argentina, 2005; pp. 6-28.

29. Kim, M.; Kim, A.C.H.; Newman, J.I.; Ferris, G.R.; Perrewé, P.L. The antecedents and consequences of positive organizational behavior: The role of psychological capital for promoting employee well-being in sport organizations. Sport Manag. Rev. 2019, 22, 108-125. [CrossRef]

30. Fletcher, D.; Arnold, R. 10 Performance leadership and management in elite sport. Manag. Elite Sport Syst. Res. Pract. 2015, 12, 162-175.

31. Peng, S.; Liao, Y.; Sun, R. The influence of transformational leadership on employees' affective organizational commitment in public and non-profit organizations: A moderated mediation model. Public Pers. Manag. 2020, 49, 29-56. [CrossRef]

32. Renz, D. The Jossey-Bass Handbook of Nonprofit Leadership and Management; John Wiley: London, UK, 2016.

33. Stuart, D. The business of sports. Co. Dir. 2013, 28, 22-26.

34. Megheirkouni, M. Leadership competencies: Qualitative insight into sport non-profit organizations. Int. J. Public Leadersh. 2017. [CrossRef] 
35. Lok, P.; Crawford, J. The effect of organizational culture and leadership style on job satisfaction and organizational commitment: A cross-national comparison. J. Manag. Dev. 2004, 23, 321-338. [CrossRef]

36. Trenberth, L.; Hassan, D. Managing the Sports Business: Introduction; Routledge: London, UK, 2013.

37. Northouse, P. Leadership: Theory and Practice, 6th ed.; Sage Publications: London, UK, 2013.

38. Salacuse, J.W. Real leaders negotiate. Univ. Bus. 2007, 10, 2-3.

39. Antoldi, F.; Capelletti, E.; Capelli, C. Reconsidering the multi-sports club business model: Designing effective new strategies in the face of environmental changes. Meas. Bus. Excell. 2016, 20, 10-27. [CrossRef]

40. Varela-Juárez, R.; Mercado-Peña, E.A. Restaurantes con servicio completo en el distrito federal entre la productividad y competitividad. RITUR 2016, 6130-6143. [CrossRef]

41. Villa, A. Liderazgo resiliente pertinente para una sociedad cambiante. Foro Educ. 2020, 34, 77-103. [CrossRef]

42. Burnard, K.; Bhamra, R. Organizational resilience: Development of a conceptual framework for organizational responses. Int. J. Prod. Res. 2011, 49, 5581-5599. [CrossRef]

43. Williams, G. Management millennialism: Designing the new generation of employee. Work Employ. Soc. 2019, 34, 371-387. [CrossRef]

44. Quintero, D. El conflicto social e historias de vida: La génesis del liderazgo y de la resiliencia comunitaria. Rev. Reflex. Saberes 2018, 9, 58-73. Available online: https:/ / revistavirtual.ucn.edu.co/index.php/RevistaRyS/article/view / 1024 (accessed on 23 August 2020).

45. Cruz, V.; Salanova, M.; Martínez, I. Liderazgo Transformacional: Investigación actual y retos futuros. Rev. Univ. Empresa 2013, 15, 13-32. Available online: https://revistas.urosario.edu.co/index.php/empresa/article/view/2871 (accessed on 23 August 2020).

46. Alfaro, E. Las Mujeres y el Deporte: Evolución y Situación real. Seminario Permanente Mujer y Deporte. Fac. CC Actividad Física y Deporte-INEF. Universidad Politécnica de Madrid. Available online: http:/ /www.munideporte.com/imagenes/documentacion/ ficheros / 20100805132024Elida\%20Alfaro.pdf (accessed on 22 August 2020).

47. Soler, S.; Moragas, M.; Vilanova, A. Catalonia: The voices of female chairs of sports clubs. In Gender Diversity in European Sport Governance; Elling, A., Hovden, A., Knoppers, A., Eds.; Routledge: New York, NY, USA, 2018; pp. $102-107$.

48. Ibáñez, M. Mujeres y Liderazgo Auténtico. ¿Podría ser una Salida para Lograr la Igualdad de Género? Available online: http:/ / repositori.uji.es/xmlui/handle/10234/168744 (accessed on 22 August 2020).

49. Wicker, P.; Feiler, S.; Breuer, C. Board gender diversity, critical masses, and organizational problems of non-profit sport clubs. Eur. Sport Manag. Q. 2020. [CrossRef]

50. Manpower Group. Talento y Liderazgo; Manpower Group MeCA: Mexico City, Mexico, 2010. Available online: http://www. manpowergroup.com.mx/uploads/estudios/Talento_y_Liderazgo.pdf (accessed on 28 August 2020).

51. De la Garza, M.T.; Carpio, J.J.; López, J.A.; Rodríguez, P. El liderazgo de servicio en relación con el involucramiento en el trabajo. Rev. Espac. 2020, 41, 30-42.

52. López-Vílchez, J.J.; Grau-Alberola, E.; Gil-Monte, P.R.; Figueredo-Ferraz, H. Relación entre los estilos de liderazgo transformacional laissez-faire y el síndrome de quemarse por el trabajo en profesores de educación secundaria. Acciones Investig. Soc. 2019, $39,223-254$.

53. Mehdinezhad, V.; Sardarzahi, Z. Comportamientos de liderazgo y su relación con la experiencia en gestión de los directores. J. N. Approaches Educ. Res. 2016, 6, 11-16. [CrossRef]

54. Báez, F.; Zurita, F.; Martínez, A.; Zagalaz, M.L. Psychometric analysis and diagnosis relationships of emotional intelligence and leadership in teachers of regulated education. RIE 2019, 37, 201-216. [CrossRef]

55. Álvarez, O.; Lila, M.; Castillo, I. Los estilos de liderazgo de la Policía Local de la Comunidad Valenciana: Una aproximación desde la teoría del liderazgo transformacional, introducción. An. Psicol. 2012, 28, 548-557. [CrossRef]

56. Baek, H.; Byers, E.H.; Vito, G.F. Transformational leadership and organizational commitment in Korean police station. Int. J. Police Sci. Manag. 2018, 20, 155-170. [CrossRef]

57. Fahlberg, B.; Toomey, R. Liderazgo de servicio: Un modelo para líderes emergentes en enfermería. Nursing 2017, 34, 48-50. [CrossRef]

58. Rojo, E.; Torres, B.; de la Fuente, A.; Oruña, C.; Villoria, F.; del Moral, I.; Maestre, J.M. La simulación como herramienta para facilitar el cambio en las organizaciones sanitarias. JHQR 2020, 35, 183-190. [CrossRef] [PubMed]

59. Viñegra, G.; Murillo, S.; Zurbanobeaskoetxea, L.; de la Rica, J.A. Atención sociosanitaria en euskadi: Modelo de gobernanza y liderazgo. Int. J. Integr. Care 2019, 19, 508. [CrossRef]

60. Ferkins, L.; Shilbury, D.; O’Boyle, I. Leadership in governance: Exploring collective board leadership in sport governance systems. Sport Manag. Rev. 2018, 21, 221-231. [CrossRef]

61. Hoye, R. Leadership within voluntary sport organization boards. Nonprofit Manag. Leadersh. 2006, 16, 297-313. [CrossRef]

62. Hoye, R.; Doherty, A. Nonprofit sport board performance: A review and directions for future research. J. Sport Manag. 2011, 25, 272-285. [CrossRef]

63. Jiang, Y.; Chen, C.C. Integrating knowledge activities for team innovation: Effects of transformational leadership. J. Manag. 2018, 44, 1819-1847. [CrossRef]

64. Ørnulf, S. Professionalization of voluntary sport organizations a study of the quality club programmer of the Norwegian football association. Eur. Sport Manag. Q. 2019, 19, 666-683. [CrossRef]

65. Megheirkouni, M. Power bases and job satisfaction in sports organizations. J. Glob. Sport Manag. 2019, 4, 271-290. [CrossRef]

66. Namai, R.; Okeyo, W. Leadership styles and performance of premier league football clubs in Kenya. Int. J. Manag. Leadersh. Stud. 2020, 2, 136-144. 
67. Barbado, J.C.; Martínez-Moreno, A. Sports Centre Workers Fitness Effects of Leadership, Engagement and Stress. Rev. Int. Med. Cienc. Act. Fís. Deporte. 2020, in press.

68. Arriola, Z.S. El liderazgo Transformacional en los Equipos Representativos Tigres de la UANL. Ph.D. Thesis, Universidad Autónoma de Nuevo León, Nuevo León, Mexico, 2019.

69. Burmaoglu, G.E. The relationship between the serving leadership and ability of managers with organizational trust of sport clubs staffs in Erzurum. J. Educ. Train. Stud. 2018, 6, 83-88.

70. Carballo, M.Á.L. Incentivo del liderazgo compartido superior. Dominio Cienc. 2019, 5, 385-400. Available online: https: / / dialnet.unirioja.es/servlet/articulo?codigo=6869928 (accessed on 30 August 2020).

71. Madanchian, M.; Taherdoost, H. Assessment of leadership effectiveness dimensions in small and medium enterprises (SMEs). Proc. Manuf. 2019, 32, 1035-1042. [CrossRef]

72. Pedraja, L.; Rodríguez, E. Efectos del estilo de liderazgo sobre la eficacia de las organizaciones públicas. Rev. Fac. Ing. Univ. Tarapacá 2004, 12, 63-73. Available online: http:/ /www.scielo.cl/pdf/rfacing/v12n2/art09.pdf (accessed on 28 August 2020). [CrossRef]

73. Carillo-Rosero, D.A.; Paredes-Núñez, A.V.; Paredes-Núñez, I.I.; Núñez-López, C.R. Reflexiones teóricas sobre el liderazgo en el desarrollo empresarial. FIPCAEC 2019, 4, 105-124.

74. Moreno, R.J.; Espíritu, R. El empowerment, el liderazgo y la innovación en empresas de servicios, como una ventaja competitiva de las medianas empresas del municipio de Tecomán, Colima, México. Desarro. Gerenc. 2014, 6, 72-97. [CrossRef]

75. Wingate, T.G.; Lee, C.S.; Bourdage, J.S. Who helps and why? Contextualizing organizational citizenship behavior. Can. J. Behav.Sci. 2019, 51, 147-158. [CrossRef]

76. Honari, H.; Goudarzi, M.; Heidari, A.; Emami, A. The relationship between transformation-oriented leadership and physical education managers' productivity in sport clubs. Proc. Soc. Behav. Sci. 2010, 2, 5495-5497. [CrossRef]

77. Alemu, S.M.; Babu, M.S. The relationship between coaches' leadership styles, team cohesion and team success: The case of premier league soccer clubs in Ethiopia. Int. J. Soc. Sci. Interdiscip. Res. 2012, 1, 1-13.

78. Milan, T. Practical Approach to an Amateur Sports Club Activities Development: Case Paimion Haka. Available online: http:/ / urn.fi/URN:NBN:fi:amk-2016121320248 (accessed on 30 November 2020).

79. Balduck, A.L.; Van Rossem, A.; Buelens, M. Identifying competencies of volunteer board members of community sports clubs. Nonprofit Volunt. Sect. Q. 2010, 39, 213-235. [CrossRef]

80. Lee, K.; Cho, W. The relationship between transformational leadership of immediate superiors, organizational culture, and affective commitment in fitness club employees. Sport Mont. 2018, 16, 15-19. [CrossRef]

81. Melnick, M.J.; Wann, D.L. Sport fandom influences, interests, and behaviors among Norwegian university students. Int. Sports J. 2004, 8, 1 .

82. Wicker, P. Willingness-to-pay in non-profit sports clubs. Int. J. Sport Financ. 2011, 6, 155.

83. Boletín Oficial del Estado (BOE). Ley 10/1990, de 15 de Octubre, del Deporte. BOE-A-1990-25037. Available online: https: / /www.boe.es/buscar/pdf/1990/BOE-A-1990-25037-consolidado.pdf (accessed on 4 August 2020).

84. Bass, B.M.; Avolio, B.J. MLQ Multifactor Leadership Questionnaire: Sampler; Mind Garden: Menlo Park, CA, USA, 1995. [CrossRef]

85. Molero, F.; Recio, P.; Cuadrado, I. Liderazgo transformacional y liderazgo transaccional: Un análisis de la estructura factorial del Multifactor Leadership Questionnaire (MLQ) en una muestra española. Psicothema 2010, 22, 495-501.

86. Asociación Médica Mundial (WMA). Declaración de Helsinki de la AMM: Principios Éticos para la Investigación Médica en Seres Humanos, AMM: Asociación Médica Mundial. 2013. Available online: https:/ /www.wma.net/policies-post/wma-declarationof-helsinki-ethical-principles-for-medical-research-involving-human-subjects/ (accessed on 4 August 2020).

87. Martínez-Moreno, A.; Morales, V.; Angosto, S. Sailing: The crew leadership. JHSE 2018, 13, 766-775. [CrossRef]

88. Niño, L.I.N.; Parra, L.P. Estilos de liderazgo y Satisfacción Laboral en personal operativo en seguridad privada. Perspectiva psicosocial intralaboral. Verba Luris 2019, 14, 99-111. [CrossRef]

89. Rivera, M.I. Liderazgo que ejercen jefas y supervisoras según auto percepción y sus colaboradores. Rev. Cienc. Arte Enferm. 2019, 4, 18-23. [CrossRef]

90. Rabanal, R.; Huamán, C.R. Tipo de liderazgo de jefes de oficina y rendimiento laboral de trabajadores administrativos. Rev. Cient. UNTRM Cienc. Soc. Humanid. 2020, 2, 26-30.

91. Morales, A.M.; Domínguez, C.; Larios, E. Estilo de Liderazgo en los docentes de ingeniería mecánica del instituto tecnológico superior de Tepexi de Rodríguez. Braz. J. Biomotricidad 2020, 2, 3113-3127.

92. Martínez-Moreno, A.; Morales, V.; Ibáñez, R. Calidad de Liderazgo en la formación inicial. Sportk 2016, 5, 103-106. [CrossRef]

93. Álvarez, O.; Castillo, I.; Molina-García, V.; Balague, G. Transformational leadership on the athletic field: An international Review. RPD 2016, 25, 319-326.

94. García-Morales, V.J.; Jiménez-Barrionuevo, M.M.; Gutiérrez-Gutiérrez, L. Transformational Leadership Influence on Organizational Performance Through Organizational Learning and Innovation. J. Bus. Res. 2012, 65, 1040-1050. [CrossRef]

95. Cuadrado, F.; Molero, F.; Navas, M. El liderazgo de hombres y mujeres: Diferencias en estilos de liderazgo y predictores de variables de resultado organizacional. Acción Psicol. 2003, 2, 115-129.

96. Cuadra, A.; Veloso, C. Liderazgo, clima y satisfacción laboral. Rev. Univers. 2007, 2, 40-56. [CrossRef]

97. Muñoz, C. Liderazgo Transformacional en la Gestión Hospitalaria. Un Estudio Empírico Sobre la Eficacia del Liderazgo y el Desempeño en Equipos de Salud del Hospital Clínico de la Universidad de Chile. Ph.D. Thesis, Universitat de Lleida, Lleida, Spain, 2019. Available online: http:/ /hdl.handle.net/10803/668315 (accessed on 12 January 2021). 
98. Mendoza, I.A.; García, B.R.; Uribe, J.F. Liderazgo y su relación con variables de resultado: Un modelo estructural. AIP 2014, 4, 1412-1429. [CrossRef]

99. Pesantez, W.G. El liderazgo transformacional-transaccional y su relación con las variables: Autoevaluaciones centrales, satisfacción, esfuerzo extra y efectividad. In Proceedings of the 24th Congreso Internacional de Contaduría, Administración e Informática, Ciudad Universitaria, Mexico City, Mexico, 9-11 October 2019.

100. Kim, S.; Magnusen, M.; Andrew, D.P.S.; Stoll, J. Are transformational leaders a double-edged sword? Impact of transformational leadership in sport employee commitment and job satisfaction. Int. J. Sports Sci. Coach. 2012, 7, 661-676. [CrossRef]

101. Darling, J.; Leffel, A. Developing the leadership team in an entrepreneurial venture: A case focusing on the importance of styles. J. Small Bus. Entrep. 2010, 23, 355-371. [CrossRef]

102. Falcão, W.R.; Bloom, G.A.; Gilbert, W.D. Coaches' Perceptions of a Coach Training Program Designed to Promote Youth Developmental Outcomes. J. Appl. Sport Psychol. 2012, 24, 429-444. [CrossRef]

103. Vella, S.A.; Oades, L.G.; Crowe, T.P. A Pilot Test of Transformational Leadership Training for Sports Coaches: Impact on the Developmental Experiences of Adolescent Athletes. Int. J. Sports Sci. Coach. 2013, 8, 513-530. [CrossRef]

104. Mora, A.; Cruz, J.; Torregrosa, M. Effects of a training program in communication Stüler of basketball coaches. $R P D 2009,3$, 299-302. Available online: https:/ / ddd.uab.cat/record/ 62646 (accessed on 21 December 2020).

105. Olusoga, P.; Maynard, I.; Butt, J.; Hays, K. Coaching under pressure: Mental skills training for sports coaches. Sport Exerc. Psychol. Rev. 2014, 10, 31-44. Available online: http://shura.shu.ac.uk/9784/1/Olusoga_et_al_(2014)_Coaching_under_Pressure_-_ MST_for_Coaches_-_FINAL_Manuscript.pdf (accessed on 12 January 2021).

106. Mascarenhas, D.R.; Collins, D.; Mortimer, P.W.; Morris, B. Training accurate and coherent decision making in rugby union referees. Sport Psychol. 2005, 19, 131-147. [CrossRef]

107. Schweizer, G.; Plessner, H.; Kahlert, D.; Brand, R. A Video-Based Training Method for Improving Soccer Referees' Intuitive Decision-Making Skills. J. Appl. Sport Psychol. 2011, 23, 429-442. [CrossRef]

108. Slack, L.A.; Maynard, I.W.; Butt, J.; Olusoga, P. An evaluation of a mental toughness education and training program for early-career English football league referees. Sport Psychol. 2015, 29, 237-257. [CrossRef] 